\title{
Challenges of Russian Fuel and Energy Complex
}

\section{Natalia Victorovna Kuznetsova}

Doctor of Economics, professor, Department of World Economy, School of Economics and Management Far Eastern Federal University, Russia, 690950, Vladivostok, Suhanova St. 8

\section{Ekaterina Vasilievna Kuznetsova}

BBA, Specialist in International Economics, M.S. in National Security and Public Safety

\section{Doi:10.5901/mjss.2015.v6n5p112}

\section{Abstract}

The research investigates the current state of Russian fuel and energy complex, presenting current statistics and analytics. The purpose of this research is to explore main areas of Russian fuel and energy complex, such as oil and gas industries, especially in terms of export and production, in order to disclose major challenges that become even more obvious in current 2014-2015 political crisis. It was discovered that though short-term prospects of Russian fuel and energy complex are not as gruesome as proposed by many, there are severe issues with the condition of infrastructure. It is beyond doubt that Russia will require foreign help in order to fix current wear and tear of infrastructure and allow Russia to renew it technological capacity that will be needed for future exploration and production. Russia has a lot of challenges in terms of its export orientation in the next 20 years as well.

Keywords: Russia, Energy Industry, Oil, Gas, Global Energy Market.

\section{Introduction}

Russian fuel and energy complex is the most important infrastructure of the Russian Federation. In the light of variety of shocks and changes that has been taking place in the past two years we analyzed the most recent dynamics: between January 2014 and February 2015 oil export has fluctuated in a small range, almost remaining unchanged, but natural gas export has decreased by 50\%, see figure 1 (Ministry of Energy of Russian Federation [MoE], n.d.-a). This dynamics gives a clue, that some variables of Russian energy industry are more sensitive than other.

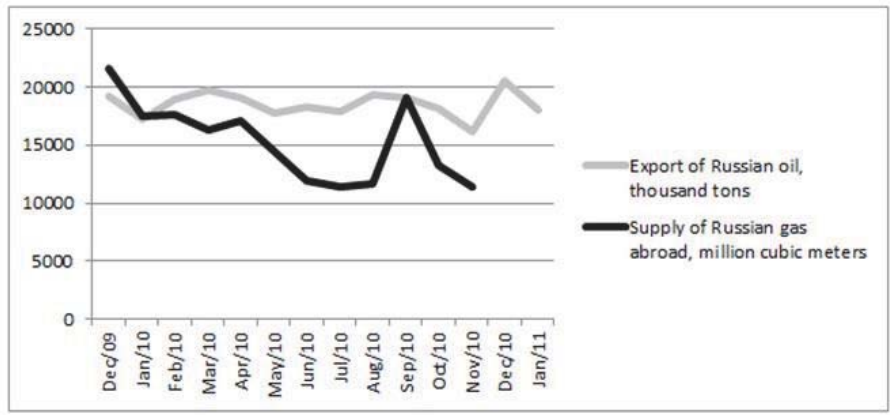

Figure 1. Natural gas and crude oil dynamics January 2014 to February 2015. Source: MoE, n.d.-a

A common belief in Russia - is that there is such a strong dependency on Russia's energy resources in the world that the industry should not suffer any unfixable changes. A common belief in the world is that Russian fuel and energy complex is collapsing. Neither of the opinions is correct. It is true, however, that Russian fuel and energy complex is more vulnerable than it seems, but its problems appear to be more subtle and fundamental. This research is dedicated to how Russian fuel and energy complex strategic problems and their solutions relate to the global integration. 


\section{Overview of Russian Fuel and Energy Complex}

\subsection{Overview}

Russia is traditionally defined by three things on the international arena: Russia has abundance of natural resources, Russia is a very influential country due to the abundance of resources, and Russia is extremely dependent on its fuel and energy complex (hereinafter FEC).

As of 2012, share of Russian FEC in both Russian GDP and Russian production/manufacturing industry is roughly $30 \%$, share in the country's budget $-51.7 \%$, share in export revenues $-65.9 \%$ (Zilberstein, 2014).

2.

Russia is one of the largest consumers of electricity, and it is sufficiently covered by its own production, see figure

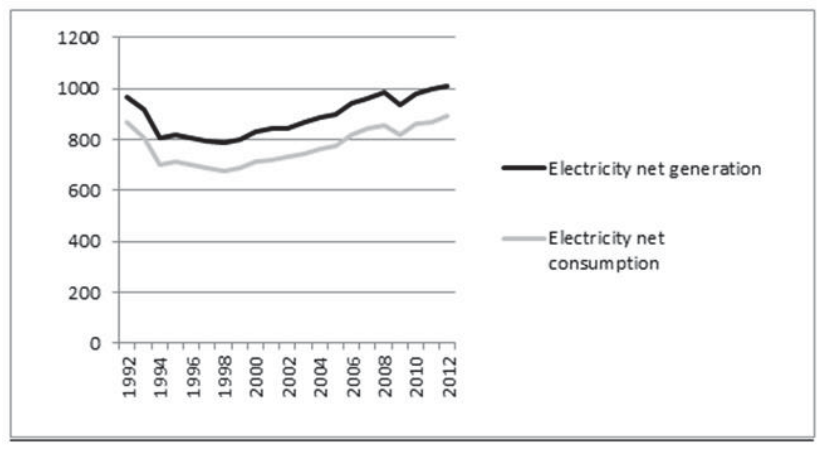

Figure 2. Electricity (billion kilowatt-hours), 1992-2012. Source: [EIA], 2013

Fossil fuels (oil, natural gas, and coal) are used to generate about $68 \%$ of total installed electricity capacity, hydropower between 15\% and 20\%, and nuclear - between 11\% and 18\% (Central Intelligence Agency [CIA], 2014a; EIA, 2014). Very small part of electricity goes for export (EIA, 2013).

Crude oil industry secures $20.2 \%$ of GDP, natural gas industry $-6.6 \%$, electricity $-2 \%$, coal $-0.8 \%$. Oil industry secures $49.7 \%$ of total Russian export, natural gas $-14.4 \%$, coal $-1.4 \%$, electricity industry $-0.2 \%$. In addition, oil industry secures $40.7 \%$ of Russian tax and customs revenues (the country's budget), natural gas $-7.4 \%$, coal $-0.4 \%$, electricity industry - 3.1\% (Zilberstein, 2014).

Before 1950 coal dominated Russian energy market. However today coal industry is outran by oil and gas industry, even though Russia has world's second largest coal reserves, and it is a sixth largest world coal producer (CIA, 2014a; EIA, 2014). Coal production mostly correlates with consumption (mostly, but not entirely), see figure 3 (EIA, 2013). Export, though remaining low, has been growing in the past decade.

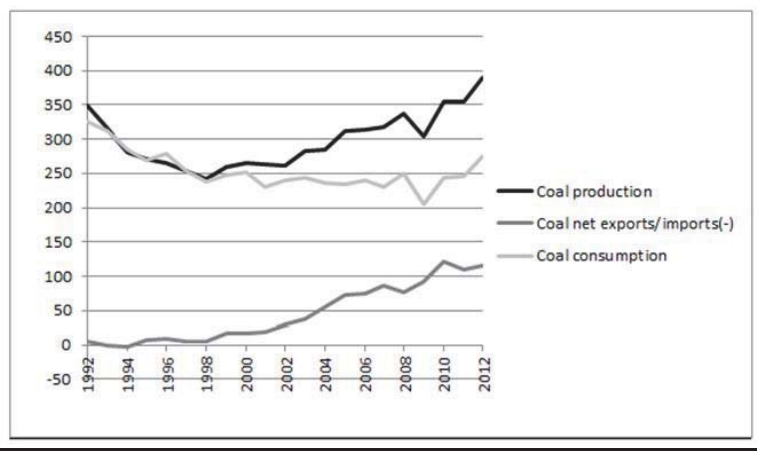

Figure 3. Coal (million short tons), 1992-2012. Source: EIA, 2013 
Since 1950 Russian energy market has been dominated by oil and gas industries.

Russia is the third world producer of crude oil and second world exporter. Russia takes eighth place in the world by its proved oil reserves (CIA, 2014a; EIA, 2014). Roughly half of the produced crude oil goes for export. Oil dynamics has been positive since $1990^{\text {th }}$, with rapid production and export growth around 2002, see figure 4 (EIA, 2013). Consumption has remained relatively on the same level, whereas production has correlated with export. Russia is also largest world exporter of refined petroleum products.

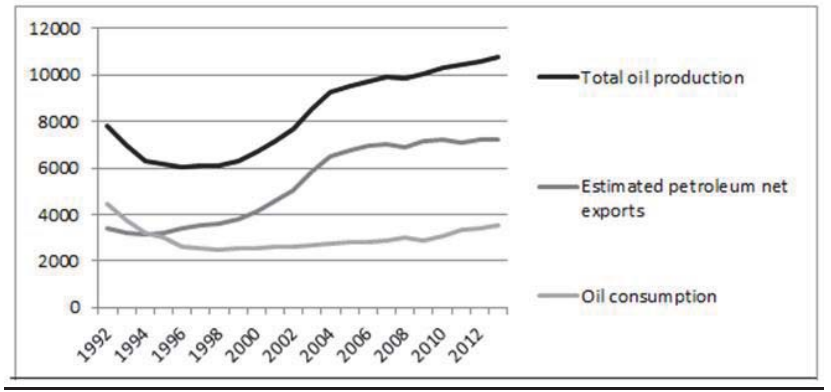

Figure 4. OIL (thousand barrels per day), 1992-2012. Source: EIA, 2013

Natural gas dynamics has been changing from low to high for the past 20 years, staying mostly in the same volume range, see figure 5 (EIA, 2013). Natural gas production has correlated mostly with consumption. Russia is second world producer and consumer of natural gas; in addition it holds most of the worlds proved natural gas reserves (CIA, 2014a; EIA, 2014). Most of natural gas goes for domestic market, however Russia is still number one world exporter of natural gas.

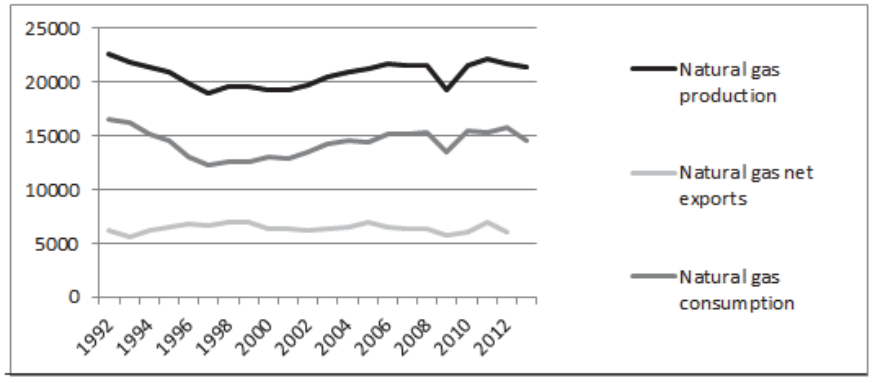

Figure 5. GAS (billion cubic feet), 1992-2012. Source: EIA, 2013

As for the nuclear power, Russia has 33 operational nuclear reactors at 10 locations with installed nuclear capacity of 23.6 gigawatts. As 16 of Russia's reactors are more than 30 years old (traditional retirement age), the Russian reactor fleet will need to be replaced with new power plants. As of 2013, 10 new nuclear reactors were under construction across Russia. Another 25 units are planned to be completed by 2025.

\subsection{Challenges for Future of Russian FEC}

The authors of the first Russian Energy Strategy, a roadmap for the strategic decision-making in Russian energy industry that was created back in 2003, declared the main idea for preservation and development of Russian FEC: "Challenge for Energy Strategy's realization is in the avoidance of such developments and circumstances in the energy sector, which objectively opposes main suggestions of the Strategy, its principles, and mechanisms of governmental energy policy" (MoE, 2003, p. 117).

The dependence of Russian economy on FEC is that strong that it is intolerable to imagine a scenario where 
deliberate or undeliberate circumstances would cut off Russian FEC from global energy market. Dependency of other countries on Russian FEC makes that idea impossible. However, in the past ten years a lot has happened that has influenced the dynamics of energy market. The past year and a half has been specifically difficult for the Russian Federation, and a lot of questions were raised in terms of future of Russian FEC.

First, it is necessary to note that there have been tremendous internal problems of Russian FEC that will require a thorough repair. Most serious problems, such as aging of infrastructure and capital assets, technological weakness of Russian FEC (which makes exploration more difficult and production less efficient), low energy efficiency, raise a lot of concern (Bushuev, 2014). The share of resources that are difficult for extraction grows (MoE, 2014a, pp. 11-19). Wear and tear of capital assets of FEC is extremely high (up to 60\%), that is in addition to the fact that capital assets renewal is slow, including all the construction works. Investments are uneven. Russian FEC still falls far behind the world scientifictechnological level in the energy industry. One of the most serious dangers of Russian fuel and energy balance is its high dependence on natural gas and low quality of energy products and services.

Second, due to the structure of the state's budget, Russia must preserve its energy export positions on traditional markets and expand its export beyond the traditional markets.

In order to fulfill both of the goals it is extremely important that Russia continues its integration with global energy business, both for the trade purposes and attraction of foreign investments, because it is questionable whether Russian economy is strong enough to single-handedly provide for the overall modernization and development of FEC and FEC infrastructure.

Third, the main problem is that fulfillment of strategically correct scenario is not only hindered by undeliberate circumstances (like for example, in the past year Urals oil prices, which account for more than $80 \%$ of Russia's export, dropped by $50 \%$ due to OPEC's oil price manipulations), but it is also hindered by circumstances that can be controlled by Russia. In the particular case of 2014-2015, these circumstances are sanctions imposed on Russia due to the Russian-Ukraine conflict, 50\% Russian currency drop, and "trash" credit ratings.

Russia has engaged in energy cooperation with many countries: it is an observer in Organization of the Petroleum Exporting Countries, member of Gas Exporting Countries Forum, The Black Sea Economic Cooperation; participates in numerous energy boards, International Energy Forum, and World Petroleum Council; participation application to International Energy Agency from Russia has been pending since 1996 (MoE, n.d.-b). So it is clear that Russia has been actively seeking ways to engage into energy cooperation and broaden the influence on energy market, but the effort keeps being interrupted by increasingly difficult political situation and domestic policy.

Domestic companies have dominated most of Russia's production and Russian government has been creating extremely difficult or impossible circumstances for foreign companies to operate in the country.

Increasingly difficult political situation, detached Russian regulatory policy, changes in the world market (U.S. shale revolution, competition for Asian market, European desire for diversification of energy supply) - all of the factors create concerns for the future of Russian FEC.

\section{Development of Russian FEC}

\subsection{Oil and Gas Export}

Europe is the most strategically important Russian trading partner on a global energy market. Approximately $79 \%$ of Russia's crude oil export (out of approximately 5 million bbl/d in 2012) and 81\% of natural gas export goes to Europe (EIA, 2014). Germany receives large part of Russian export - approximately $13.8 \%$ of crude oil and $24 \%$ of natural gas. Next largest receivers of Russian crude oil in Europe are: Netherlands (approx. 11\%), Poland - 9.6\%, Belarus - 8.4\%, Finland - 3.8\%, Sweden, Lithuania, Italy - each 3.6\%, France - 3.5\%, Spain - 3.4\%, UK - 2.4\%, Bulgaria - 2.3\%, Hungary $-2.2 \%$. After Germany largest importers of Russian natural gas are: Italy (approx. 11\%), France - 6\%, UK $6 \%$, other Western Europe - 10\%, Eastern Europe - 24\%. By other estimates largest receivers of Russian oil are: Netherlands (30\%), Italy (14\%), Germany (11\%); and natural gas: Germany (27\%), Italy (17\%), and Poland (9\%) (MoE, 2014b, page 2).

Russia supplies around 30\% of Europe's gas demand each year: Eastern Europe depends on Russia for more than $75 \%$ of their gas needs, Germany and Italy - 25-50\%, France and Netherlands depend in lesser degree (Hodges, 2014). Russian volumes in Europe's energy supply are very large to be easily and quickly replaced, and it would not be cheap, however there are few dangers for Russia.

European Union's ambition to create European energy union has started with passing the Third Energy Package, which means that Russia could not both own and control pipelines on the EU territory (Holodny, 2015). Once fully 
implemented Energy Package would break up existing monopoly allowing more liberty and competition. The general idea behind the union is that EU would establish a single transparent market for electricity and gas, and would build energy transportation network (Dempsey, 2015). This would change the market - for example Lithuania had complained that Gazprom (Russian gas monopoly) was blocking the competition. However the plan has certain obstacles. Energy supply in Europe is spread unevenly - it would be difficult and costly to integrate disparate systems of energy transportation. In addition new pipelines carrying fuel from different regions would also be needed. Most of the energy companies in EU were or are state-owned - so the national sensitivities would need to be taken into account. Lastly, as Jason Anderson of World Wide Fund pointed out - there is inconsistency in strategic views on reorganization of the market around either fossil fuels or around renewable energy (Harvey, 2015).

Europe is actively seeking ways to reduce its dependence on Russia. One of the suggested options is getting fuel from Azerbaijan through pipeline in Turkey (Tully, 2015). The shipments will be destined only for 2020 once Trans Adriatic Pipeline is completed. Azerbaijan's natural gas total export is 5.55 billion cubic meters, and the country produces 17.86 billion cu m, whereas EU imports 420.6 billion cu m (CIA, 2014b; CIA, 2014c). Azerbaijan is a great example that Europe's efforts to reduce dependence on Russian resources will need to go to much greater extents in order to diversify supplies, which is possible, but highly difficult considering either production capacities of nearby countries or financial expenses to build and support long-distance trade networks.

Europe has been reaching out to the United States. United States have lifted its ban on exporting of gas, and it is planned that by 2018 two plants will be finished for exporting of natural gas potentially for markets in Europe and Asia (Casey, 2014). Here, however again - lack of infrastructure and US reserves will play the biggest role in defining whether the project will worth it both for US and EU.

For now Europe is also increasing its storage of gas and is looking into increasing liquefied natural gas (LNG), Lithuania and Poland are both investing in new receiving terminals. Lithuania started importing LNG from Norway (Holodny, 2015). Here, Russia, as well as United States also plan to get into picture. Russia has been working towards building more LNG plants (which will be discussed in the next section). Gazprom recently announced that Russia can beat potential for US LNG exports to Europe on price ("Russia Outcompetes the U.S. When It Comes to LNG," 2015). Despite the suggestion that US LNG plants, that are currently seeking permits for export and several more are being built, Russia will probably still be in an advantage due to the transportation costs. Despite of that, Europe and US cooperation will give EU some leverage against Russia.

Shale gas and oil revolution in US that is widely discussed in terms of new sources for Europe is questioned, as lower oil prices slow down the industry (Sharma, 2015). Igor Sechin, the top of Russia's oil producer Rosneft believes that the shale boom will be short lived as US production increase is not supported by the reserves very well ("US shale oil boom could become next 'dotcom bubble', says Russian oil boss," 2015). Russian officials do not consider shale as the best working option for today's Russia, as there are more efficient opportunities ("Fedun: extraction of shale oil in Russia is not of interest," 2015). Europe's own shale explorations has been disappointing: Poland that has been viewed as European's biggest hope for sources of natural gas trapped in shale had little success both in terms of actual reserves and commercial viability of the industry (Cunningham, 2014).

It is important to point out however, that as of today, it is not only Russia that is losing due to existing hostile environment, Europe is suffering its share as well. Thus, in 2014 president Putin announced that one of the most expected projects - South Stream pipeline, that would deliver gas to some European countries bypassing Ukraine (which now hosts part of one of the major pipelines from Russia to Europe ) would not be built (Venturini, 2015).

Despite all the controversy with natural gas, crude oil exports are expected to rise in 2015, as announced by Russian Energy Minister Alexander Novak (Soldatkin \& Golubkova, 2015).

Asia is the second largest receiver of Russian energy export. Asia receives $18 \%$ of crude oil export and all of the Russian LNG through Sakhalin LNG plant, located in the Far East of Russian Federation (EIA, 2014). After completing Eastern Siberia-Pacific Ocean oil pipeline in 2010, Russia was able to export more oil to Asian market. China receives $9.8 \%$ of total crude oil export, followed by Japan who receives $3.6 \%$ of crude oil export. Japan also receives $76 \%$ of LNG, followed by South Korea - 20\% and China - 3.50\%. The majority of the LNG has been contracted to Japanese and South Korean buyers under long-term supply agreements. Indonesia is a largest receiver of Russian petroleum products approximately $16.20 \%$.

Russia is actively seeking ways to continue energy-dialogue with China, considering the country as an important strategic partner (MoE, n.d.-c). May, 2014 Russia's Gazprom signed a 30 year contract to supply natural gas to China (Holodny, 2015). Power of Siberia pipeline, which would transport natural gas to Far Eastern countries and Primorskii Krai of Russia despite the rumors of being postponed, is promised to be completed by 2019 ("Energy firm confirms Power of Siberia faces no delay and is on time," 2015). For Russia, expansion to the Asia means diversification of export, which 
is a very valuable type of progress considering desperate attempts of Europe to reduce dependence on Russian energy. The questions are too complex to be answered that early still rise. First of all, whether Russia will be able to compete with US and Australian LNG, and secondly, what kind of partnership with China is realistic both in terms of price and timeframes.

Turkey is another important partner - receiving 19\% of Russian natural gas export (EIA, 2014). Turkey depends on Russian gas on 50-75\% (Hodges, 2014). Russian relationship with Turkey, just as relationship with its Asian partners, is warmer than those of with Europe. Russia and Turkey has been negotiating on Turkish Stream pipeline (Tully, 2015).

Americas is not the main energy trade partner, however United States is a second largest receiver of Russian petroleum products export - 15.7\% (EIA, 2014). In addtion, US is important for Russia in terms of business between the two countries, where one side has access to more resources and the other side has access to investments and technology. These relationship should be as valuable for Russia as its trade activity with Europe.

Today, Russia makes an emphasis on growing demand on energy resources in developing countries, especially China and India, which might lead to growth of global demand by $45 \%$ by 2035 (MoE, 2013, p. 8). Russia expects that Asian demand for Russian energy will grow and take a bigger share in it export; Russia also expects that share of FEC in GDP will decrease to $15 \%$ by 2035 , however so far no progress has happened. Russia aims for decreasing dependence from export to Europe (Ministry of Economic Development of Russian Federation [MoED], 2013, p. 188).

\subsection{Exploration and Production of Oil and Gas}

If current level of oil production remains the same, explored oil fields will suffice for more than 30 years. Exploration of new fields, technological capacity, and producing capacity will be highly important for Russia in the next 20 years. As for natural gas - share of resources located in locations difficult for extraction and exploration (either climate or geographical conditions) will increase, as well as share of multi-component gas that will require complicated infrastructure (MoED, 2013, p 193).

One of the most serious problems on the way of development of Russian FEC is protectionism policy that is so heavily used by Russia. Defending its economic interests Russia forces out a lot of partnership that can bring technology and investments in Russian FEC.

Rosneft is the largest oil producer in Russia, accounting for $40 \%$ of the Russian oil production ("Rosneft at a Glance," n.d.). Rosneft is mainly state-owned company (69.5\%), British Petroleum owns $19.75 \%$ and the remaining $10.75 \%$ of shares are publicly traded. British Petroleum reportedly relied for almost $20 \%$ of its profit on Rosneft for the first half of 2014 (Baker, 2014). In 2003 BP formed TNK-BP, which was sold to Rosneft in 2012-2013, due to what former president of TNK-BP called administrative bullying by Russian authorities (Baker, 2014). Now Rosneft has more debt than actual profit, however company suggests it can satisfy its financial obligation by 2017 (Bierman , 2015). Lukoil is second largest oil producer - accounting for $16.6 \%$ of Russian crude oil production and $16.5 \%$ of Russian crude oil refining; the company is privately-held ("Lukoil - general information," n.d.). Lukoil is largest privately owned oil and gas company in the world by proved oil reserves, and second privately owned by oil production. After roughly 8 years of partnership, American ConocoPhillips sold its $30 \%$ stake back to Lukoil (Shiryaevskaya\& Klump, 2012). Surgutneftegaz is a privately held company accounting for roughly $12 \%$ of Russian crude oil production ("Surgutneftegas - the company today," n.d.). Gazprom Neft accounts for roughly 6\%; it is a subsidiary of state-owned Gazprom (EIA, 2014; "Gazprom Neft at a glance," n.d.). Tatneft accounts for $5 \%$ of Russian total crude oil production. Transneft - near monopoly over Russia's pipeline network, nearly completely owned and ran by the government, transports about $88 \%$ of all crude oil and about $27 \%$ of oil products produced in Russia. Transneft accounts for majority of export pipelines (EIA, 2014).

Gas production in Russia is dominated by Gazprom, which accounts for $18 \%$ of the global gas reserves and $74 \%$ of Russian gas output; $50.23 \%$ of Gazprom belongs to Russian Federation, the company also issues shares to outside investors ("Gazprom today," n.d.; "About Gazprom," n.d.). Gazprom dominates Russia's natural gas pipeline system (EIA, 2014). Independent company Novatek accounts for roughly $10 \%$ of total Russian natural gas production ("Novatek About us," n.d.).

Russian independent and especially foreign investors have had difficulties with accessing the business and opportunity to realize new projects. However, it is important to note that Russian government is making steps towards liberalization of the market. For example, in 2013 new editions to Federal Law 117 "About gas export" allows larger range of companies to export LNG; thus, Gazprom monopoly for export of LNG is over ("Important changes in Russian law about gas export," 2013).

Energy Strategy-2030 established three stages of development, with first stage to be completed around 20132014; first stage was largely focused on renewal of infrastructure. As of $2012-2013$ only roughly $62 \%$ of planned 
investments were brought to the industry (MoE, 2014a, pp 11-12). According to new prospects of Project ES-2035, Alexander Novak reported that Russia will require approximately 2.5 trillion of dollars by 2035 for development of fuel and energy complex ("Novak: energy strategy project will require $\$ 2.5$ trillion of investments," 2015). Most of the future investments suggested by Russian government would go towards oil and gas industry - from $61 \%$ to $64 \%$ ("Annual investments in Russian FEC by 2035 were evaluated at $\$ 130$ milliards," 2014).

In 2014 Investments in oil extraction in Russia has grown 10\% compared to 2013. Alexander Novak reported that it allowed increase of extraction in strategic projects that had that kind of goal. It is important to remind that oil extraction has grown $0.6 \%$ in 2014 reaching to the level Russian Energy strategy offers to leave it at (526.7 million ton/year) ("Investments in exploration of oil in Russia by 2014 grew 10\%," 2015).

Russian FEC has most serious problems with infrastructure. Wear and tear of FEC capital assets is almost $60 \%$ by new estimations, with more than $83 \%$ of buildings, $70 \%$ of boilers, $70 \%$ of power grid equipment, and $66 \%$ of heating networks that were built before 1990 (MoE, 2014a, pp 11-12). It is also estimated that wear and tear of capital assets in electricity energy industry is 40\%, gas industry $-60 \%$, oil industry - 80\% (Pluzhnik, Saprikina, 2013, pp. 41-50). In 2010, roughly $70 \%$ of main-truck oil pipelines were more than 20 years old, and half of them is being exploited for more than 30 years (Pluzhnik, Saprikina, 2013, pp. 41-50). Despite the statistics, rates of renewal of capital assets in the past 10 years has been roughly $2 \%$, excluding oil extraction - 4\%. Alexander Novak in 2015 noted that in the past three years capitals assets were renewed for 10\% ("Volume of investments in FEC was 3.5 trillion of rubble," 2015).

In addition share of resources that require more financial investments, such as fields located in harsh climate or far from infrastructure, are high in number for both gas and oil industry (MoED, 2013, p 190). Roughly 77\% of proved oil reserves are located in working field, however 60\% are exhausted (MoED, 2013, 187). About 67\% of resources are difficult for extraction.

It is doubtful that Russia can attract investments for both exploration and production of resources and modernization of infrastructure from within its own borders (either government or inside investors). Main bulk of investments goes for development of oil industry; it is still attractive for investors (Naumkina, Naumkin, 2013). Gas and oil production and extraction infrastructure is the most attractive for foreign investors. It is even more important for Russia in terms of its technological inferiority and growing quantity of resources difficult for extraction. It is necessary for Russia to attract technologically progressive partners.

Western Siberia is the main exploration and production region. It is a main oil producing region, accounting for nearly two-thirds of Russia's total production (EIA, 2014). Production in Western Siberia depends highly on improving the production economics - significant portion of reserves still remains in the field. Large reserves of natural gas are also in Western Siberia. Samoltor and Priobskoye are two largest fields in West Siberia, accounting for about 20\% of the West Siberian production; exploration and production in the fields is secured by Rosneft. Other large oil fields in the region include Mamontovskoye and Salymskoye fields. Urengoy is the second largest natural gas field in the world ("Urengoy Gas Field," n.d.). Urengoy is licensed to Gazprom, as well as Yamburg and Medvezhie fields. All of the three field have seen output decline in recent years. Number of gas developments in Western Siberia are under way. Shell that had previously secured access to Western Siberia had to withdraw October 2014 due to sanctions (Torres, 2014).

Urals-Volga Basin accounts for about $22 \%$ of Russia's total output and used to be the largest producing region (EIA, 2014). Ural has the largest explored resources of natural gas (more than $90 \%$ percent of Russia natural gas) (MoED, 2013, p. 190). Tatneft operates the largest field in the region - Romashkinskoye field; the field has already reached its peak production, and will likely produce until 2030.

Though it will be very hard to substitute Western Siberia and Urals production, exploration and production in East Siberia, Russian Far East, Yamal Peninsula (Arctic Circle) is strategically important for Russia in terms of expansion efforts, as the traditional regions are in decline.

Eastern Siberia has some reserves, however the exploration has been slow in the region (EIA, 2014). Rosneft's oil production growth is due to the East Siberia. Vankor oil and gas field started its production in 2009, and has dramatically increased production of the region and has significantly contributed to Russia's oil production. Gazprom is heavily investing Eastern Siberia. Several international oil companies has been working in the region as well.

Far East, mainly Sakhalin gives only 3\% of Russia's total production (EIA, 2014). Sakhalin Island contains large oil and gas fields. Projects Sakhalin 1 (Chayvo, Odoptu, and Arkutun-Dagi) and Sakhalin 2 (Lunskoye and PiltunAstonkhskoye fields) are consortium to locate and produce oil and gas. Exploration in the region has been growing. Gazprom along with several international companies has been investing in the area. The Sakhalin Energy's LNG plant (at the Sakhalin 2) has been successfully operating since 2009. Project partners have planned to set up additional trains with first to start going in 2017-2018. However, the new trains will need new sources of gas. Thus, Gazprom has been exploring the Kirinskoye Block in Sakhalin 3. 
Siberia and Far East oil extraction grew 4 million ton in 2014, which is roughly 7.5\% to 2013 ("Investments in exploration of oil in Russia by 2014 grew 10\%," 2015).

Russian Arctic (Yamal Peninsula/Arctic Circle) is mostly promising in terms of gas production; crude oil development is relatively new for the region (EIA, 2014). Generally, Arctic is promised to contain $22 \%$ of the world's uncovered oil and gas, with majority of the resources located within Russian territory (Belinksi, 2015). Gazprom and international companies have been investing into the region. ExxonMobil signed an agreement with Rosneft to develop Arctic shelf. September 2014, Rosneft and ExxonMobil discovered gas and oil reserves in Kara Sea (in Arctic Ocean), but due to sanctions Exxon had to abandon $\$ 700$ million project and subsequently withdrew from the Arctic (Belinksi, 2015). British Petroleum cancelled planned partnership with Russian Rosneft in Arctic as well.

Russia, lacking the technical expertise, had to draw its attention towards Asian partners. In the case of proposed Yamal LNG plant licensed to Novatek (80\%) and French oil giant Total (20\%) that lost a lot of investments due to sanctions, China announced it would provide Total with $\$ 15$ billion to invest in Yamal LNG Project (Belinksi, 2015). Yamal LNG is set to start export in 2017. That action supposedly has a political meaning as well - introducing Russian invulnerability, however realistically in global market - no country in protected.

North Caucasus, Black Sea, Caspian Sea, Timan-Pechora and Barents Sea are also valuable fields and basins of oil and gas exploration, however exploration there is small. Lukoil has been actively developing deposits in North Caspian and in Timan Pechora. Gazprom is planning to develop field in Pechora Sea, as well as Shtokman LNG plant in Barents Sea.

All three LNG plants are extremely important: projects Sakhalin-2 and Yamal LNG, Shtokmansk field - all of the projects should bring around $11 \%$ of total gas production in Russia and supply more than $50 \%$ of estimated future gas export to Europe by 2020 (MoE, 2014b, page2). Another LNG plant - Vladivostok LNG might be postponed until better times ("Gazprom considering shelving Vladivostok LNG project," 2014).

Two of the most serious concerns for Russian FEC today - lack of financial resources and severe technological inferiority. Despite the sanction the business interests of western companies has not ceased to exist: for example it was reported that ExxonMobil continued working with Russia on some projects despite the sanctions ("ExxonMobil sues Russia claiming it overpaid $\$ 500 \mathrm{mn}$ in Sakhalin-1 tax," 2015). In addition to harsh political environment, low oil prices wrap up bulk of investments in new exploration.

\section{Conclusion}

\subsection{Discussion}

Russian FEC is vital for Russian economy. The current role it plays in the budget is irreplaceable. However, today FEC requires large amount of investments in order to continue functioning in the long term. The prospects of Russian FEC are not that gruesome in a short term, it would be too extreme to suggest that. The crisis has definitely brought a lot of separation anxiety between Russian business and foreign partners both in terms of trade and exploration/production projects. Despite all of that, we can see that Russian FEC stays afloat and there are solutions already to be found and pursued, like orientation towards Asia. However, the cooperation that had been previously established cannot be replaced - both for Russia and its foreign partners. The main conclusion is that Russian FEC does not provide independence to the country, on the opposite - high dependence on FEC must ideally make the country more considerate when it comes to foreign and business policy because not only Russian business interests lose something, but more importantly - the potential for innovation is getting lost as well.

In the long term Russia might seriously suffer from the lack of investments and technological inferiority that will prevent further development of FEC. Russian FEC is very near to be worn out in terms of its capital assets and infrastructure, which automatically puts the whole industry on stake. In context of Russia, it means not only putting energy security on stake, but also budget security on stake. This will have tremendously dangerous consequences for the unprotected businesses, social layers, and the whole country.

\subsection{Scope for further research}

Future research must be oriented towards further developments concerning the political crisis and its impact on FEC. New Energy Strategy of Russian Federation is estimated to be completed by summer 2015. The research into new strategy will allow to see aspirations for FEC of Russia and it will show how the situation is thought to be handled. 


\section{References}

About Gazprom. (n.d.) Gazprom. Retrieved March 20, 2015, from http://www.gazprom.com/about/

Annual investments in Russian FEC by 2035 were evaluated at $\$ 130$ milliards. (2014, July 24). Interfax. Retrieved from http://www.interfax.ru/business/387620

Baker, S. (2014, December 18). BP's Dudley Relives Russian Nightmare Alongside Rosneft Boss. Bloomberg. Retrieved from http://www.bloomberg.com/news/articles/2014-12-18/bp-s-dudley-relives-russian-nightmare-alongside-rosneft-boss

Belinksi, S. (2015, April 2). Putin May Have Last Laugh Over Western Sanctions. Oil Price. Retrieved from http://oilprice.com/Energy/ Energy-General/Putin-May-Have-Last-Laugh-Over-Western-Sanctions.html

Bierman, S. (2015, March 4). Rosneft Posts Profit as Accounting Change Mutes Ruble Impact. Bloomberg. Retrieved from http://www.bloomberg.com/news/articles/2015-03-04/rosneft-reports-quarterly-profit-after-accounting-method-switch

Bushuev, V. (2014, February 17). Project energy strategy of Russia till 2035 [power point presentation]. Retrieved from http://www. energystrategy.ru/ab_ins/source/Bushuev_ES-2035-17.02.14.pdf

Casey, M. (2014, September 10). Natural gas exports set to take off as Energy Department approves two new projects. Fortune.

Retrieved from http://fortune.com/2014/09/10/natural-gas-exports-set-to-take-off-as-energy-department-approves-two-new-projects/

Central Intelligence Agency. (2014a, June 20). The world Factbook. Central Asia: Russia [online database]. Retrieved from https://www. cia.gov/library/publications/the-world-factbook/geos/rs.html

Central Intelligence Agency. (2014b, June 17). The world Factbook. Europe: European Union [online database]. Retrieved from https://www.cia.gov/library/publications/the-world-factbook/geos/ee.html

Central Intelligence Agency. (2014c, June 23). The world Factbook. Middle East: Azerbaijan [online database]. Retrieved from https://www.cia.gov/library/publications/the-world-factbook/geos/aj.html

Cunningham, N. (2014, October 13). No Shale Revolution For Europe. Oil Price. Retrieved from http://oilprice.com/Energy/NaturalGas/No-Shale-Revolution-For-Europe.html

Dempsey, J. (2015, March 23). The Slow Erosion of Gazprom's Grip Over Europe. Carnegie Europe. Retrieved from http://carnegie europe.eu/2015/03/23/slow-erosion-of-gazprom-s-grip-over-europe

Energy firm confirms Power of Siberia faces no delay and is on time. (2015, March 24). Siberian Times. Retrieved from http://siberiantimes.com/business/siberianexport/news/n0163-energy-firm-confirms-power-of-siberia-faces-no-delay-and-is-ontimel

ExxonMobil sues Russia claiming it overpaid $\$ 500 \mathrm{mn}$ in Sakhalin-1 tax. (2015, April 2). Russia Today. Retrieved from http://rt.com/business/246181-exxonmobil-russia-lawsuit-taxes/

Fedun: extraction of shale oil in Russia is not of interest. (2015, March 3). Ria Novosti. Retrieved from http://ria.ru/economy/ 20150303/1050696103.htm|\#ixzz3VvWfU84b

Gazprom considering shelving Vladivostok LNG project. (2014, October 17). Global Gas Transport. Retrieved from http://www.global gastransport.info/archive.php?id=16791

Gazprom neft at a glance. (n.d.) Gazprom-Neft. Retrieved March 20, 2015, from http://www.gazprom-neft.com/company/at-a-glance/

Gazprom today. (n.d.) Gazprom. Retrieved March 20, 2015, from http://www.gazprom.com/about/today/

Harvey, F. (2015, February 25). EU's energy union must overcome serious obstacles. The Guardian. Retrieved from http://www.theguardian.com/environment/2015/feb/25/eu-energy-union-must-overcome-serious-obstacles

Hodges, P. (2014, May 14). Europe faces Russian gas and oil supply risk over Ukraine. ICIS.com. Retrieved from http://www.icis. com/blogs/chemicals-and-the-economy/2014/05/europe-faces-russian-gas-and-oil-supplies-risk-over-ukraine/

Holodny, L. (2015, January 14). Russia is losing control over the European gas market. Business Insider. Retrieved from http://www.businessinsider.com/russia-losing-european-gas-2015-1\#ixzz3VujQITrr

Important changes in Russian law about gas export. (2013, December) Norton Rose Fulbright. Retrieved March 3, 2015, from http://www.nortonrosefulbright.com/knowledge/publications/111285/

Investments in exploration of oil in Russia by 2014 grew 10\%. (2015, March 2). Neftegas.ru. Retrieved from http://neftegaz.ru/news/ view/135356

Lukoil - general information. (n.d.) Lukoil. Retrieved March 23, 2015, from http://www.lukoil.com/static_6_5id_29_.html

Ministry of Energy of Russian Federation. (2003, August 28). Energy Strategy of Russia till 2020. Approved by the Decree N1234-r of Government of the Russian Federation.

Ministry of Economic Development of Russian Federation (2013, March). Prognosis for the long-term socio-economic development of Russian Federation till 2030.

Ministry of Energy of Russian Federation. (2013, March). Roadmap of energy cooperation between Russia and EU till 2050.

Ministry of Energy of Russian Federation. (2014a). Project Energy Strategy of Russia till 2035. Retrieved from http://minenergo.gov. ru/upload/iblock/621/621d81fofb5a11919f912bfafb3248d6.pdf

Ministry of Energy of Russian Federation. (2014b, January). Energy Dialogue Russia - EU, $13^{\text {th }}$ general report.

Ministry of Energy of Russian Federation. (n.d.-a). Statistics information. Retrieved January 23, 2015 from http://minenergo.gov.ru/ activity/statisticl

Ministry of Energy of Russian Federation. (n.d.-b). International cooperation. Retrieved January 25, 2015 from http://minenergo.gov. rulactivity/co-operation/

Ministry of Energy of Russian Federation. (n.d.-c). Energy Dialogue Russia-China. Retrieved February 6, 2015 from http://minenergo. 
gov.ru/activity/co-operation/china/

Naumkina, T.V. Naumkin, A.P. (2013). Investments and fuel and energy complex of Russia. Modern scientific research and innovations. N12. Retrieved from http://web.snauka.ru/issues/2013/12/29745

Novak: energy strategy project will require $\$ 2.5$ trillion of investments. (2015, March 18). Ria Novosti. Retrieved from http://ria.ru/economy/20150318/1053212554.html

Novatek - About us. (n.d.) Novatek. Retrieved March 20, 2015, from http://www.novatek.ru/en/about/general/

Pluzhnik, M.V., Saprikina, M.A. (2013). Energy security and energy security provision challenges in modern Russian economy. Russian entrepreneurship, N16(238), pp. 41-50

Rosneft at a Glance. (n.d.) Rosneft. Retrieved March 03, 2015, from http://www.rosneft.com/about/

Russia Outcompetes the U.S. When It Comes to LNG. (2015, March 17). Stratfor. Retrieved from https://www.stratfor.com/image/russiaoutcompetes-us-when-it-comes-Ing

Sharma, G. (2015, March 30). Decline of US Shale Plays Not Clear Cut as Oil Price Stays Low. Forbes. Retrieved from http://www.forbes.com/sites/gauravsharma/2015/03/30/decline-of-us-shale-plays-at-lower-oil-prices-not-as-clear-cut/

Shiryaevskaya, A., Klump, E. (2012, August 22). ConocoPhillips Sells Russian Venture Stake to Partner Lukoil. Bloomberg. Retrieved from http://www.bloomberg.com/news/articles/2012-08-22/conocophillips-sells-russian-venture-stake-to-partner-lukoil-1-

Soldatkin, V., Golubkova, K. (2015, March 11). Russia's energy minister sees crude oil exports rising. Reuters. Retrieved from http://www.reuters.com/article/2015/03/11/us-russia-crisis-novak-oil-idUSKBNOM70QM20150311

Surgutneftegas - the company today. (n.d.) Surgutneftegas. Retrieved February 23, 2015, from http://www.surgutneftegas.ru/en/ about/todayl

Torres, N. (2014, October 5). Shell suspends Gazprom Siberia shale JV. PetroGlobal News. Retrieved from http://petroglobalnews. com/2014/10/shell-suspends-gazprom-siberia-shale-jv/

Tully, A. (2015, March 19). Europe One Big Step Closer To Weaning Off Russian Gas. Oil Price. Retrieved from http://oilprice.com/ Latest-Energy-News/World-News/Europe-One-Big-Step-Closer-To-Weaning-Off-Russian-Gas.html

U.S. Energy Information Administration. (2013, May 30). Overview data for Russia [Statistics]. Retrieved from http://www.eia. gov Icountries/country-data.cfm?fips=RS\&trk=m\#tpe

U.S. Energy Information Administration. (2014, March 12). Overview analysis for Russia [Statistics]. Retrieved from http://www.eia. gov/countries/cab.cfm?fips=RS

Urengoy Gas Field. (n.d.) OilVoice. Retrieved March 5, 2015, from http://www.oilvoice.com/well/Urengoy_Gas_Field/d0ab6c183166.aspx

US shale oil boom could become next 'dotcom bubble', says Russian oil boss. (2015, February 10). The Guardian. Retrieved from http://www.theguardian.com/business/2015/feb/10/us-shale-oil-next-dotcom-bubble-russia-rosneft-igor-sechin-opec

Venturini, G. (2015, March 7). Pipeline Geopolitics: From South Stream To Blue Stream. Counter Currents. Retrieved from http://www. countercurrents.org/venturini070315.htm

Volume of investments in FEC was 3.5 trillion of rubble. (2015, March 2). TVC. Retrieved from http://www.tvc.ru/news/show/id/62595

Zilberstein, O. (2014, May 5). Assesment of the energy industry role in structure of the Russian economy and formation of national power safety indicators. Economy and modern management: theory and practice: compendium of reports of $32^{\text {nd }}$ international scientific-practical conference. Retrieved from http://sibac.info/14671 